\title{
Labour Laws And Women Workers Of The Export Processing Zones In Karachi
}

\author{
Asma Manzoor \\ \& \\ Nasreen Aslam Shah \\ Women's Studies \\ University of Karachi
}

\begin{abstract}
The selection of Karachi Export Promotion Zone (EPZ) is inspired by the fact that this city being the centre of industrial and economic activity attracts an everincreasing number of job seekers from across the country. EPZs are an integral part of the expanding global market. Procurement of cheap and easy-to-control labour are the prerequisites of a market-based economy. Concentration of markets in developed countries and the establishment of production units in the less developed or slow developing countries mirrors political power imbalance. As women are the focus of this study, the assessment of the status of female factory workers is the centre point of this paper. Whereas women have always been part of waged-work outside the home, the phenomenon of women factory workers is a product of the World Wars, which encouraged women to work in factories as men were on the war front. This paper draws upon a research whose findings are not dramatically different from similar studies conducted elsewhere, however it presents a fresh perspective on the experiences of women working in a poor country. This paper presents both quantitative as well as qualitative data about 330 women working in 25 industrial units of varying production capacities. The paper also examines the absence of the phenomenon of labour laws in the Karachi Export Processing Zone and examines its impact on the lives of women workers.
\end{abstract}

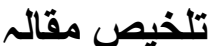

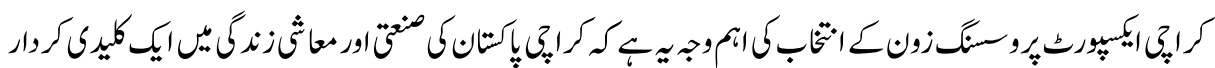

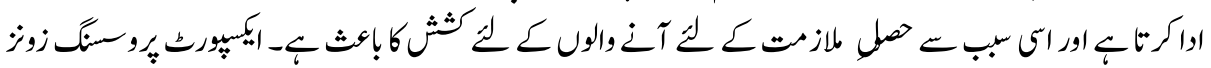

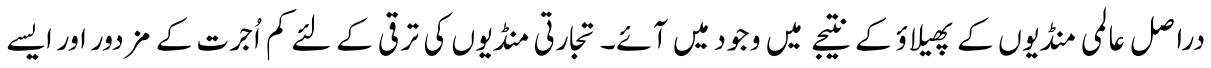

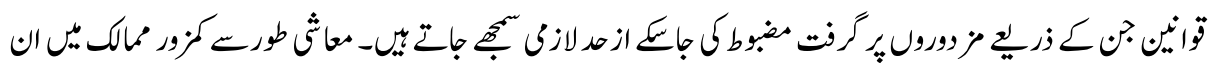

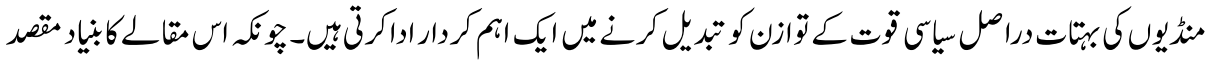

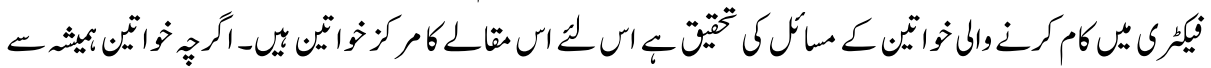

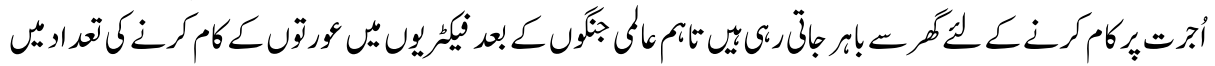

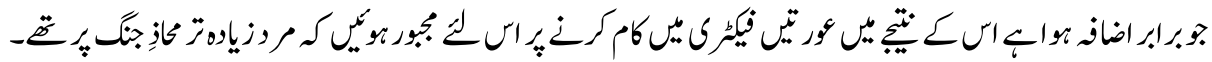

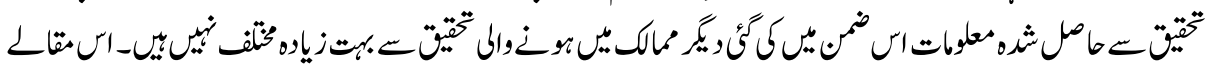

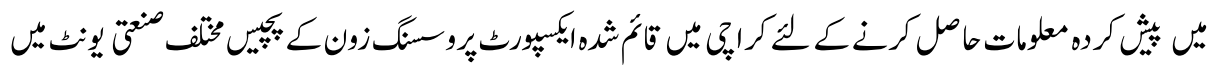

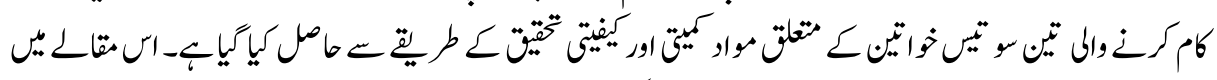

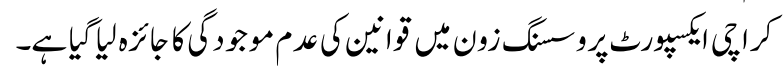


Key Words: Export processing zone, women, Maternity benefit, Trade union, Laws

\section{Introduction}

One of the most debated outcomes of the growth and expansion of global market is the appearance of an increasing number of Export Processing Zones (EPZs) across the globe where an incredible number of employees, mostly young women, work (Romero, 1996). Drawing upon qualitative and quantitative data collected in Pakistan's EPZ in Karachi, this study seeks to explore the relationship between women workers, the EPZs, and the economic development of Pakistan. The findings of this research have raised a host of questions regarding the nature, causes, and effects of this multifaceted relationship, particularly in the context of women workers and the EPZ, which is the centre point of this exploratory work.

To a casual eye, located adjacent to the Landhi Industrial Area (Extension) over an area of approximately 500 acres, the EPZ in Karachi is a place where on each working day of the week buses bring in workers from all over the city. The EPZ, whether in Karachi or anywhere else, however, is more than a structure. It is a symbol of development planning and strategies. Defined by Milberg and Amengual in their ILO sponsored study, EPZs are 'those regulatory spaces in a country aimed at attracting export-oriented companies by offering these companies special concessions on taxes, tariffs and regulations (Milberg \& Amengual, 2008).' This definition, thus, selects two major components that form the basis of any EPZ, i.e., export-oriented companies, and concessions to attract investors and producers. In this process, 'imported materials undergo some degree of processing before being (re)imported again'(ILO: Geneva,1998). Thus, EPZs have not only increased exports but they have been instrumental in 'attracting export-oriented foreign direct investment (FDI) (Akhtar, 2003).'

Tracing the history of the birth of EPZs, Akhtar comments that the phenomenon of export-processing zones is 'a part of broader context of structural changes in global economic development (Akhtar, 2003).' Most of the countries affected by these structural changes were the recently freed former colonies. The global restructuring, in turn created among several other things, inequalities, transnationalisation of production, and feminisation of labour.

Where do we place the workers in this definition? As studies on EPZs show, workers, indeed, are tacitly subsumed in the category of concessions offered to attract exportoriented companies. It is in this context of workers vs. EPZs and industrial growth and development in general, that Mathew Roberts in his study 'Export Processing Zones in Jamaica and Mauritius' discusses the relationship between EPZs and the economic development theory. Examining the five-stage theory of development by Walter Rostow ${ }^{1}$ 
and of the industrial 'big-push' theory of Rosenstein-Rodan (Rosenstein, 1943), Roberts sums up the debate by stating that EPZs are 'intended to attract externally the capital for investment that is not domestically available and quickly raise industrial production', meeting two of Rostow's conditions. The unique role of the public sector and the structure of an EPZ is meant to achieve Rostows' third condition, Rosenstein-Rodan's call for social overhead capital, and [to] overcome structural rigidities (Roberts, 1992).'

The EPZs are of various types e.g. free trade zones, duty free zones, free investment zones, and offshore zones. Citing Jean Currie (1979:1), Murayama and Yokota explain that 'the early free trade zones allowed imports and export free from custom formalities with the purpose of facilitating the speedy re-export of goods, the victualling of ships, and the development of the commercial sector (Murayama, 2008).' Wong and Chu, explaining the differences in the locations of free trade zones and the EPZs, say that unlike their predecessors, i.e. the free trade zones located normally near a port 'an EPZ need not necessarily be located adjacent to a port (Wong \& David ,1984).' An exportprocessing zone could be defined as 'a clearly demarcated industrial zone which constitutes a free trade enclave outside a country's normal customs and trading system where foreign enterprises produce principally for export and benefit from certain tax and financial incentives (International Confederation of Free Trade Unions,1996).' Another simple and popular definition of EPZ is 'an industrial estate usually a fenced-area of 10 to 300 hectares specializing in manufacturing for export zones (M. Engman \& E. Pinali, 2007).'

\section{The Beginning of the EPZs}

The concept of the EPZ, Murayama and Yokota note, 'is said to have originated from free trade zones established in major ports such as Gibraltar, Singapore and Hong Kong during the eighteenth and nineteenth centuries (Murayama, 2008).' The world's first Free Trade Zone, Shannon Industrial Estate, was established in Ireland in 1959 to revitalise the old Shannon Airport and to promote employment within a rural area and generate revenue for the Irish economy. It was hugely successful, and is still in operation today (Annual Report English, 2010). In Asia, the first EPZ was established at Kandla in 1965 by the Indian government (Vittal, 1977). China followed in 1966 (Kuo, 1977) and South Korea created its EPZ (Masan EPZ) (Chvl, 1977). By the 1970s countries such as Malaysia, Sri Lanka, Thailand, and the Philippines also had their EPZs.

\section{Purpose of the EPZs}

EPZs described as the 'engine of outward-oriented economic growth' are typically seen 'as an instrument for expanding and modernizing the host economy through additional investment/capital formation, technology transfer and employment generation' explain 
Kusago and Tzannatos (Kusago \& Tzannatos, 1998). Although EPZs are fast appearing in all economies of the world (ILO, 2008) their organisation and working pattern vary from country to country. ${ }^{2}$ It is true that the main motivation behind the establishment of these zones is to attract foreign investors by offering them low-cost labour (Kamal, 2000).

In most of the developing countries, EPZs were established to promote export-led growth through manufacturing process. Several incentives are given to attract investment into the country, like tax holidays, duty-free imports and exports, infrastructural facilities, etc, and exemption from implementation of some labour laws and payment of contribution of social security schemes for the workers (Sklair, 1988).

Workers in the EPZs are severely exploited by their employers. The latter utilise all the benefits provided by their respective governments and flout even the minimum standards provided under labour laws that are applicable in the EPZs. The workers have no job security. Hire and fire policy is freely exercised by the employer. While in some countries, the wages in EPZs are slightly more than paid in the normal industrial zones, in many countries, the minimum wages provided under policies by the concerned governments are not paid in actual terms in most of the EPZs. A large number of the workers are employed on contract basis. Social welfare benefits like PF (Provident Fund), ESI (Employee State Insurance) and maternity benefits are not implemented. Mostly young girls of around 18-22 years are employed and they are forced not to enter in the marriage contract or bear babies while they remain employed. Sexual harassment, abusive language, and maltreatment by the supervisors are quite common in the EPZs. Though labour laws are legally applicable in the EPZs, governments and labour officials are not bothered about ensuring their implementation.

In some countries, employers provide boarding facilities to the work force on a bachelor basis. Workers are lodged in these boarding houses but are not allowed to meet outsiders during their employment with the EPZs. Even minimum amenities like sufficient treated water, sanitation, health and hygiene conditions are not provided in these boarding houses, which are ill ventilated and crowded like a boot camp. Young women, who come mostly from distant areas, are not allowed to freely go outside for shopping, religious services, or for social interactions (Jayanthakuamaran, 1997).

Trade unions are not tolerated in the EPZs, though unions are not banned according to law applicable within the jurisdictions of EPZs. The slightest suspicion of any effort made by the workers to get organized is met with severe repression, often resulting in job termination. Employers even resort to physical as well as criminal assaults. Another tactic resorted by the investors is the threat to shift their businesses to countries where labour is comparatively cheap and workers are organized (Bhagwati, 1988). As most of the industries situated in the EPZs belong to the hi-tech modern sector of the economy and 
depend on the international open market, it would be reasonable to expect that wages are relatively high. In reality, remuneration is usually as low as or worse than in local enterprises (Kamel, 1990).

Social security is by no means guaranteed either. Production targets are often set excessively high in order to reduce the wages actually paid. Workers find themselves obliged to take work home to avoid losing money (ICFTU, 1996). Thus as instability of job and precarious employment are the rule, it is common practice in the maquilas of Central America to dismiss workers at the end of the year to avoid seniority payments and related rights. Interestingly the same workers will be rehired for want of discontinuity of services just a few days later (Kamel, 1990). Another exploitative factor is that the workers are subjected, more than elsewhere, to fluctuations in demand. When demand is high, they have to work overtime and production rates are set excessively high. When demand falls, workers lose their jobs. Sometimes, workers are locked in the plant and forced to work overnight to meet production targets. Many workers are forced to take work home to finish their individual target. Sometimes they work until one in the morning and they are not paid anything for those extra hours (Kelleher, 1992).

The 'feminization' of employment has been accompanied by deterioration in pay levels. In South Korea, at the end of the ' 80 s, women earned on average one half of what their male colleagues in the same sector were paid. Most women were confined to repetitive tasks in production while men usually moved on quickly to better-paid supervision or maintenance jobs. Even today, managers are mostly male and gender biased. Laws relating to maternity leave are not respected. They believe that any specific protection for women workers is bound to result in lower productivity and higher production costs. Sexual harassment is endemic in the EPZ's. While sexual harassment is frequent, complaints are rare because they automatically lead to the dismissal of the woman who has virtually no chance of having her case heard at a tribunal for the purpose.

In the Dominican Republic workers in the zones work in such conditions that fail to meet minimum industrial health and safety standards. The employers also keep a check on how many times workers go to the toilet by forcing them to ask for tickets. Management also delivers, reluctantly, authorizations for medical visits during working hours. In Honduras, some factories gave their workers' amphetamine injections to prevent them from collapsing after working continuously 48 hours (Matsebula, 2002).

However, in Pakistan, the EPZ ordinance IV adopted in 1980 totally suspends national labour legislation in the zones, including the right to form or belong to a trade union. Workers cannot take part in strike action to defend their rights. While this situation within the EPZs is viewed positively by certain trade unionists, what it really shows is just how bad the situation regarding workers' rights is (Diwan, 1993). In 1982, in 
Pakistan, the government formally banned the right to strike in the zones. 'No employee' says the ordinance that applies specifically to the export processing zones 'has the right to refuse work, hold up work, or go on strike. No employee may begin, continue, instigate, incite or force others to take part in a strike or to support one (Diwan, 1993).' Furthermore, workers in the EPZs do not have the right to form trade unions following the suspension of all labour legislation in the zones. The concerned authorities in Pakistan proudly announced their willingness to exchange trade union rights for foreign investment. At the end of 1992, the then Federal Minister for Finance Mr. Sartaj Aziz, addressing a group of Japanese businessmen in Tokyo, promised that 'the labour laws of Pakistan will not be applicable in the special industrial zones created by the government (Diwan 1993).' In 2000, the Government of Pakistan withdrew all the labour laws of Pakistan from the export processing zones.

\section{Methodology}

For this research, the universe of population is the KEPZ and nearby localities from where women workers come. The first task for conducting this study was to identify the number of industries in which women are employed. To identify the total number of working industrial units in KEPZ Export Promotion Bureau (EPB) and KEPZA were contacted. During our meetings, they informed that garments, stuffed toys, and plastic industrial units have more women workers now as compared to other units. For this study in selected industrial units, each woman worker had the same chance of inclusion in the sample. Total 330 women workers were interviewed from 25 factories located in KEPZ. Due to the nature of the problem and type of respondents, the researcher used the simple random sampling for this research.

In this research both quantitative and qualitative research methods are used to explore various aspects of the challenges faced by women working at Karachi Export Processing Zones (KEPZ). Following are the details of these two methods.

\section{a) Quantitative Research}

For both quantitative and qualitative research, one needs to create questionnaire. A questionnaire is simply a list of questions that a researcher prepares for the respondent to answer. Questionnaire for this research was prepared in simple-to-understand Urdu language. The questionnaire was designed to seek information regarding the following key areas of this research:

- Women workers personal profile that included questions regarding age, marital status, level of education and training.

- Family profile of the workers- nuclear or joint, urban or rural, migrant or local, family income, and housing. 
- Nature, type and title of work, nature of appointment, wages, working hours, including overtime and work on holidays, wage deductions, and fine impositions.

- Experience of verbal, physical, and sexual abuse or threat of these at work.

- Humiliation for being factory worker

- Devices to resist face or challenge the above violations of their rights as workers and as human beings.

Before administering the questionnaire, an effort was made to explain to the respondents the nature and purpose of the research. Although the respondents were assured of confidentiality and anonymity, it was evident from their looks that they some of them doubted the credibility of the researcher's assurances.

With the help of prepared questionnaire women respondents were asked the questions which were recorded on the questionnaire itself in the presence of the respondents. This method allowed the researcher ample time to note respondents' attitude towards their work and observe the physical conditions under which they work. Baseline information was also collected on the family background and socio-economic category of the respondents such as age, marital status, literacy level, and other relevant household details, working conditions, effects on their health, family and household activities, and suggestions about improvement in working conditions for women.

\section{b) Qualitative Research}

To collect qualitative information, this researcher conducted in-depth interviews with some of the respondents. These case studies proved to be a source of far greater information as compared to the information generated through the questionnaires.

Case studies are an important part of social science research informed by feminist awareness. In their makeup, case studies are the first person narratives. In their application and usefulness, case studies erase several fallacies about persons, events, and happenings that form the core of the research. Case studies also construct a proper perspective of the research problem. For this study, 12 case studies were collected.

Interviews could not be conducted within the factory premises, as it was time consuming. Home visits were made for this purpose. After initial hesitancy, the respondents agreed to interviews at their homes. Single sittings usually lasted from one to two hours. Often, a second visit was required; in some cases, the respondents or their families denied the interviews when this researcher arrived at their doorstep. Interviews were not recorded nor photographs were taken due to the respondents' and their family members' objection. During home sessions, privacy at a desirable level was hardly experienced, as majority of the houses of the respondents were small and all the family members had free access to

all the areas of the house. In addition, other members freely intervened and in some 
instances quipped in before the respondent could give her answer. This emerged as a serious challenge to the authenticity of the information. Efforts were made to verify the information with the field observations, and by assessing the responses of other women workers on the similar subject.

At both the places, factory and the home, respondents were reluctant and hesitant to answer the questions. In addition, the family chores, and the presence of parents, siblings, and children distracted the respondents. Some respondents in turn questioned me and asked how this research was going to benefit them.

Direct contact with these industrial units revealed that they were not willing to share any information regarding workers and many of them refused to conduct interviews with women workers. The process, therefore, was changed and direct contacts were made with the women workers and interviews were conducted at their homes. Researcher personally contacted the workers after the factory hours. Another strategy adopted was to contact the KEPZ Authority who contacted the industrial unit in-charges and arranged visits of the units where researcher contacted the women workers. It was quite difficult to access women workers and in some instances, the researcher had to wait on the gates of industrial units. The administrative staffs of the industrial units were reluctant to give information about the units.

The interview schedule consisted both open-ended and close ended questions. By closeended questions, we usually get the statistical data and by open-ended questions, we get extra information that is not gained by close-ended questions. With the help of prepared questionnaire women respondents were asked the questions which were recorded on the questionnaire itself in the presence of the respondents. This method allowed the researcher ample time to note respondents' attitude towards their work and observe the physical conditions under which they work.

\section{Results and Discussion}

Five years back when I first began to work on this theme, I had faint notions about women working in the KEPZ. During my initial visits to the Zone, my contacts remained limited to the offices of the management of various factories, as entrance to the work floor required permission. In 2005 and around that time only ninety-two industrial units were operational. Today, at the time of compiling this research, two hundred and ten units are in full operation. KEPZ is a male world, governed by male norms of business and human interaction. Similar to the home, where men are in power and women under their control, similarly males are in authority in KEPZ and women are at the lowest ladder. 
KEPZ workers represent a cross section of women of Pakistan, in terms of cultural norms, family characteristics, social stratification, and economic divisions. Karachi being the hub of Pakistan's industry, and by virtue of being the first city to establish EPZ in Pakistan, offers numerous opportunities for job hunters.

An interesting view regarding marital status emerges from data. When asked to share their views about the hiring rules in the context of workers' marital status at the time of hiring, $98.48 \%$ of the respondents were of the view that unmarried women workers were preferred, while $1.51 \%$ was of the view that married women workers were also hired. This reflects the global trend of EPZs where factories hire unmarried women because they have less family responsibilities as compared to married women. They are more energetic and can do work for long hours and are not expected to apply for maternity leave or benefits.

Related to the above, is the information about the age of the respondents in the context of hiring by the employers. Findings confirm the presence of younger women in the KEPZ. It shows a preponderance of young women (45.74\%) between the age group of 16 to 20 years at the time of conducting this survey. The next category, age wise is of those in the group of 21 to 25 years $(32.72 \%)$. The combined number of these two categories emerges as an overwhelming number of younger women as compared to the number of older women, i.e. of the age group of 26-30 years $(8.78 \%), 31-35$ years $(5.15 \%)$, and the age group of 36-40 years and above $(4.54 \%, 3.03 \%)$. Recruitment policies are highly informal. Hiring rules flout approved protocol for announcing vacancies. The 330 respondents verified that jobs to which they were appointed were not advertised and that they came to know via verbal communications.

Table - 1

Distribution of the respondents according to the nature of job

\begin{tabular}{|l|c|c|}
\hline Nature of Their Job & Frequency & Percentage \\
\hline Permanent & 38 & $11.51 \%$ \\
\hline Temporary & 289 & $87.57 \%$ \\
\hline Seasonal & 3 & $0.90 \%$ \\
\hline Total & $\mathbf{3 3 0}$ & $\mathbf{1 0 0 \%}$ \\
\hline
\end{tabular}

Table -2

Distribution of the respondents according to a written contract at the time of hiring

\begin{tabular}{|l|c|c|}
\hline Written Contract Done at the Time of Hiring & Frequency & Percentage \\
\hline No & 330 & $100 \%$ \\
\hline Total & $\mathbf{3 3 0}$ & $\mathbf{1 0 0 \%}$ \\
\hline
\end{tabular}


Recruitment policies are highly informal. Hiring rules flout approved protocol for announcing vacancies. The 330 respondents verified that jobs to which they were appointed were not advertised and that they came to know via verbal communications. Following the appointment, some were given a short training, explaining the nature of work. All appointments are made on a temporary basis. For this research, $87.57 \%$ respondents were working on temporary bases; only $11.51 \%$ said they had a permanent job. The reason, easy to speculate is circumventing labour laws, and making labour cost cheaper to allure foreign investors. Permanent jobs fall into administrative category and carry more benefits as well. No written formal contracts and appointment letters are issued. This forces workers into personal appeasement of their supervisors and line-incharges. As jobs, remain vulnerable at each single moment, the pressure of losing jobs further forces the workers into obedience. Respondents expressed unanimous views about employers' selection criteria of hiring unmarried women $(98.48 \%)$. In the absence of employers' response to this trend, one can only draw conclusions based on similar known global practices of preferring young and unmarried women to work in EPZs. They are more energetic and can do work for long hours and are not expected to apply for maternity leave or benefits.

Table -3

Distribution of the respondents according to retention of job during pregnancy

\begin{tabular}{|l|c|c|}
\hline Retention of Job During Pregnancy & Frequency & Percentage \\
\hline Yes & 297 & $90 \%$ \\
\hline No & 33 & $10 \%$ \\
\hline Total & $\mathbf{3 3 0}$ & $\mathbf{1 0 0 \%}$ \\
\hline
\end{tabular}

Provision of decent work and maternity leave runs parallel to each other. Unlike most factories outside the KEPZ, 90\% respondents have pregnancy /maternity leave facility; $10 \%$ of the respondents expressed fear that they would be fired from their job on declaring pregnancy. They could be rehired. 100\% respondents replied that they get the maternity leave.

Table -3.1

Distribution of the respondents according to if yes then getting maternity benefit

\begin{tabular}{|l|c|c|}
\hline If Yes then Getting Maternity Benefit & Frequency & Percentage \\
\hline Yes & 29 & $9.76 \%$ \\
\hline No & 268 & $90.23 \%$ \\
\hline Total & $\mathbf{2 9 7}$ & $\mathbf{1 0 0 \%}$ \\
\hline
\end{tabular}

Whereas $90.23 \%$ said that they get no maternity benefit in terms of money, but $9.76 \%$ replied that they get maternity benefits 
Table -4

Distribution of the respondents according to getting sick leave during illness

\begin{tabular}{|l|c|c|}
\hline Get Sick Leave During Illness & Frequency & Percentage \\
\hline Yes & 295 & $89.39 \%$ \\
\hline No & 35 & $10.60 \%$ \\
\hline Total & $\mathbf{3 3 0}$ & $\mathbf{1 0 0 \%}$ \\
\hline
\end{tabular}

Table -4.1

Distribution of the respondents according to getting sick leave at what conditions

\begin{tabular}{|l|c|c|}
\hline Get Sick Leave at What Conditions & Frequency & Percentage \\
\hline After Deducting Salary & 224 & $75.93 \%$ \\
\hline After Reducing Annual Leave & 71 & $24.06 \%$ \\
\hline Total & $\mathbf{2 9 5}$ & $\mathbf{1 0 0 \%}$ \\
\hline
\end{tabular}

Provision of sick leave, in certain cases, is more important even then a salary structure. 89. $39 \%$ affirmed the provision of sick leave; $10.60 \%$ said it was not provided. More important than the provision is the question that how many avail of it. Some expressed a fear that applying for sick leave might cost them job loss. Firing a worker is hassle free for the employers in the absence of Labour Laws and ban on unionisation. Employees once sacked lose their chances for reemployment in the factory forever. Factories allowing a maximum fourteen days sick leave per annum do it at the cost of making deductions from the workers' salary as a penalty. In some cases, deductions are made in the form of reducing the annual leave facility.

Usually companies facilitate workers by giving them breaks to improve their work efficiency otherwise they get tired which affect productivity. Another facility is availability of meals in canteens on subsidised rates. Some factories do not have canteen facilities. Majority of the respondents appreciated the provision of a separate retiring room facility for women; a small number however reported sharing it with male workers.

Visit-time to toilets and bathrooms is strictly regulated. All the respondents replied that there were separate washrooms for women workers, though the number of washrooms varies from factory to factory. Whereas $71.51 \%$ of the respondents had access to wash rooms as per their need, $14.54 \%$ said that they could go only thrice a day; some $(3.93 \%)$ even were restricted only to two visits. Of course, all could use the bathrooms during break-time. In informal discussions, the workers seemed to agree with bathroom visit restrictions, as frequent visits would slow down production target for which they might be penalised by imposition of fines and deductions from their salaries. It would also deprive them of cash awards they get on exceeding the set production target. 
For the same reason, i.e. delay in meeting the pre-set target, workers cannot leave their work-seat to go and drink water. Water, when needed is brought to the workstation $(84.24 \%) ; 15.75 \%$ said that they go thrice a day during work and drink it from the water cooler, placed at one point.

\section{Labour Laws}

Table -5

Distribution of the respondents according to factory having trade union

\begin{tabular}{|l|c|c|}
\hline Factory have Trade Union & Frequency & Percentage \\
\hline No & 330 & $100 \%$ \\
\hline Total & $\mathbf{3 3 0}$ & $\mathbf{1 0 0 \%}$ \\
\hline
\end{tabular}

Table -5.1

Distribution of the respondents according to if no then does the trade union necessary

\begin{tabular}{|l|c|c|}
\hline Does Trade Union Necessary & Frequency & Percentage \\
\hline Yes & 324 & $98.18 \%$ \\
\hline No & 6 & $1.81 \%$ \\
\hline Total & $\mathbf{3 3 0}$ & $\mathbf{1 0 0 \%}$ \\
\hline
\end{tabular}

Labour rights violations are common. All the respondents were found aware of the absence of trade unions; it is not allowed in the zone. Majority of the respondents unanimously said that it is the right of the workers, and therefore it is necessary to have trade unions through which workers' issues could be resolved (Table-5). When asked about women's participation in trade unions, out of $98.18 \%$ of the respondents who were in favour of trade unions, $88.88 \%$ said that women should participate; $11.11 \%$ said it is better for women to stay away (Table, 5.1) from such activity because they believe that it is purely men's domain to participate in political activities. Some of them said that there is no need of a trade union, as normally they do not have any problems, which need to be resolved through it.

Table -6

Distribution of the respondents according to occurrence of strike calls in the factory

\begin{tabular}{|l|c|c|}
\hline Does Their Any Strike Calls in the Factory & Frequency & Percentage \\
\hline Yes & 118 & $35.75 \%$ \\
\hline No & 207 & $62.72 \%$ \\
\hline Don't Know & 5 & $1.51 \%$ \\
\hline Total & $\mathbf{3 3 0}$ & $\mathbf{1 0 0 \%}$ \\
\hline
\end{tabular}

Despite the absence of unions, workers have resorted to work strikes or strike threats some respondents $(35.75 \%)$ told. It happened because of poor quality of canteen food, 
some workers called it for a demand of increase in salary and once it was called because the production target was not achieved in time and factory refused to pay the overtime. The issues were resolved and the strikes were called off after the intervention of the zone's authority. When asked about whether workers have the right to strike, $98.48 \%$ said that it is the right of worker to go for strike if their demands are unacknowledged.

\section{Some of the Resistance Strategies}

Like women working under similar situations, women working in the EPZ also applied certain strategies to resist exploitation by the management and male-co-workers. When asked what strategies they apply against any form of abuses, majority said 'nothing'. This 'doing nothing' does not merely reflect victims' passivity towards these heinous crimes; it shows their vulnerable situation. Fear of more harassment, escalation of threats, consequences of job loss, social censure- all together renders them inactive. Silence, as we all know, often reflects resistance.

\section{Summation}

The denial of freedom of association and the right to bargain collectively for workers has deepened a sense of deprivation in the workers' psyche who are already silenced by the fear of the power of the rich and the wealthy in Pakistan's highly segmented and stratified society. Thus, absence of trade unions, sudden termination, excessive work, use of abusive language, sexual harassment, fear of parental/family withdrawal of permission to work, keeps women silent and under stress. Added to this, lack of alternative employments and jobs is another significant factor that shapes women's decision to continue work despite all the odds. Indeed, more analytical studies are required to explore the complex relationship between the patriarchal conceptualisation of marriage and dowry and the capitalistic pattern of industrial growth, globalisation, marketing, and women's wage earning.

\section{Recommendations}

Given below are suggestions as a way forward:

- Labour Laws must be implemented in the Pakistan's EPZs to ensure and protect worker's rights.

- Efforts should be made by academic institutions, institutes of public administration, and NGOs to build an opinion in favour of the implementation of labour laws.

- Efforts should be made to convince KEPZA to follow the anti-gender harassment policies and to hold periodical seminars and consciousness raising workshops for male and female employees on their premises. 
- Women Development Ministry should establish liaison with women workers in the KEPZ and the EPZA for the protection of women workers' rights.

- Fringe benefits like medical coverage, insurance, maternity leave and maternity benefits should be facilitated. In case of post-partum period, women should be provided flexible work hours.

- Facility for baby care should be provided on the premises for lactating mothers.

\section{End Notes}

1 For details of his theory, see, Walter W. Rostow. (1960). The Stages of Economic Growth: A Non-Communist Manifesto. Cambridge: Cambridge University Press.

2 For more discussion on this aspect see, Murayama, Mayumi and Nobuko Yokota. 2008. Revisiting Gender Issues in Export Processing Zones: The Cases of South Korea, Bangladesh and India. Institute of Developing Economies (IDE).

\section{References}

Akhtar, Mohammad Hanif. (2003). "An Evaluation of Karachi Export Processing Zone: A Preliminary Investigation," in The Pakistan Development Review, 42 (4), pp. 927-940.

Annual Report English (2010) Annual Report Irish Shannon Development, Retrieved on 15 July, 2012.

Bhagwati, N. Jagdish (1988). "Export Promoting Trade Strategy Issues and Evidence." In The World Bank Research Observer, vol. 3, No.1, pp. $27-57$.

Chvl, Hahn Sang (1977) ' Current Status of Free Export Zones in Republic of Korea' in Export Processing Zones in Asia: Some Dimensions. Tokyo: Asian Productivity Organizaion, pp. 57-59.

Diwan,Tasneem,(1993). Labour laws exemption for EPU, Discussion paper.

ICFTU (1996). Trade Unionism and Export Processing Zones in Selected Countries of Asia. In Free Labour World, No. 4, Singapore.

ILO (2008) "Report of the InFocus Initiative on Export Processing Zones (EPZs): latest Trends and Policy Developments in EPZs" Governing Body Report, Geneva March 2008 Available online: http://www.ilo.org/wcmsp5/groups/public/ ed_norm/relconf/documents/meetingdocument/wcms_223.pdf090. 
ILO: Labour and social issues relating to export processing zones (Geneva, 1998), TMEPZ / 1998, p. 3.

International Confederation of Free Trade Unions, (1996). Worlds Apart: Women and the Global Economy, NY: ICFU, p.23.

Jayanthakuamaran, K. \& John Weiss (1997). "Export Processing Zones in Sri Lanka: a cost benefit appraisal." In Journal of International Development, Vol. 9, No. 5, pp. 727-737.

Kamal, Muhammad Rowshan (2000). 'Bangladesh' in Ashok Kumar Kundra ed. Asia's Export Processing Zones and Science Parks in Global Markets. Tokyo: Asian Productivty Organization, pp. 1-11.

Kamel, Rachael (1990).The Global Factory: Analysis and Action for a New Economic Era, Philadelphia: American Friends Service Committee, p. 94.

Kelleher, T. (1992). EPZs: A Global View. Export Processing Zones as an Instrument For Economic Development. Seminar paper, Shannon, May 19.

Kuo, C. O. (1977) 'Export Processing Zones in the Republic of China' in N. Vittal ed. Export Processing Zones in Asia: Some Dimensions. Tokyo: Asian Productivity Organizaion, pp. 51-53.

M. Engman, O Onodera., \& E. Pinali, E. (2007). Export processing zones: Past and future role in trade and development. OECD Trade Policy Working Papers, no. 53 , p. 14.

Matsebula, B. (2002). Investors threaten to close plant in Swaziland over labour action, Durban: The Mercury, p. 22.

Milberg, William and Matthew Amengual (2008). Economic Development and Working Conditions in Export Processing Zones: A Survey. Geneva: ILO, p. 1.

Murayama, Mayumi and Nobuko Yokota (2008). Revisiting Gender Issues in Export Processing Zones: The Cases of South Korea, Bangladesh and India. Institute of Developing Economies (IDE), p 2.

Roberts, Mathew W. (1992) Export Processing Zones in Jamaica and Mauritius: Evolution of an Export-Oriented Development Model. San Francisco: Mellen Research Foundation, pp.23-24. 
Romero, Ana T. (1996). Export Processing Zones: The Social and Labour Issue. In ILO World Labour Report, Johannesburg: ILO.

Rosenstein-Rodan, P. (1943). 'Problems of Industrialization of Eastern and South-eastern Europe', Economic Journal, 53: 202-11.

Sklair, L. (1988). Foreign Investment and Irish Development: A Study International Division of Labour in the Mid-West region of Ireland. In Progress in Planning:29 (whole issue), pp.149-217.

Takayoshi Kusago and Zafiris Tzannatos .(1998). Export Processing Zones: A Review in Need of Update. Washington D.C. The World Bank, p.4.

Vittal, N. (1977)'Export Processing Zones in India' in N. Vittal ed. Export Processing Zones in Asia: Some Dimensions. Tokyo: Asian Productivity Organizaion, pp. 5456.

Wong, Kwan-Yiu and David K.Y.Chu (1984) 'Export Processing Zones and Special Economic Zones as Generators of Economic Development: The Asian Experience1, Geografiska Annaler, 66 B, pp.1-16.

Asma Manzoor is Co-operative Teacher in the Centre of Excellence for Women's Studies, University of Karachi.

Dr. Nasreen Aslam Shah is Professor in the Department of Social Work \& Director of the Centre of Excellence for Women's Studies, University of Karachi. 